\title{
The Clinical Pathology Characteristics and Tetanus Quick Stick Evaluation for Tetanus Patients in Daegu Emergency Medical Center
}

\author{
Seung Jin Lee, Soon Ok Lim, Jae Yeop Jeong, Min Jeong Park, and Ju Eun Park \\ Department of Laboratory Medicine, Daegu Catholic University Medical Center, Daegu 705-718, Korea
}

\begin{abstract}
Tetanus has high lethality and can cause serious complication, so it is very important to have a quick and exact checkup and treatment. In this study, we conducted a study about clinical characteristics and types of tetanus patients in Daegu Emergency Medical Center and we studied possibility of Tetanos Quick Stick (TQS) as a selective check up to treat tentanus by comparing the results of local checkup kit measured from tetanus quick stick developed to check up tetanus antibody titer and results measured from ELISA (Enzyme-Linked Immunosorbent Assay). The result of the study showed that tetanus happens more to males, and by looking at season, tetanus happened most in summer (from June-August) as 19 cases (45.3\%), and when patients come to the emergency medical center, the diagnosis name was electrolyte imbalance 14 cases (33.3\%), peripheral nerve 11 cases (26.2\%), Meningitis 8 cases (19.0\%), drug addiction 7 cases (16.7\%), and the patients who are diagnosed as tetanus at the beginning of hospitalization was 2 cases (4.8\%). The result of TQS usefulness by comparing with ELISA, in TQS, 42 people was positive and 478 people was negative. it was positive when the result was over $0.1 \mathrm{IU} / \mathrm{mL}, 48$ people was ELISA positive while 472 people was negative. TQS checkup has accuracy of $98 \%$, sensitivity of $83.3 \%$, specificity of $99.5 \%$, positive predictability of $95.2 \%$ and negative predictability of $98.3 \%$. The evaluation of current immunity statuses of tetanus patients is available for TQS checkup, and it has an advantage of preventing side effects coming from the injection of unnecessary vaccine and immunoglobulin, and it is thought that it can give help to emergency checkup and treatment at the beginning.
\end{abstract}

Keywords: Emergency medical center, Tetanus, Tetanos quick stick

This is an Open Access article distributed under the terms of the Creative Commons Attribution Non-Commercial License (http://creativecommons.org/licenses/by-nc/3.0) which permits unrestricted non-commercial use, distribution, and reproduction in any medium, provided the original work is properly cited.

Copyright () 2014 The Korean Society for Clinical Laboratory Science. All rights reserved.
Corresponding author: Seung Jin Lee

Department of Laboratory Medicine, Daegu Catholic University Medical Center, Daegu 705-718, Korea

Tel: 82-53-650-4146

E-mail:kamtsj@hanmail.net

Received: December 11, 2013

Revised: March 20, 2014

Accepted: March 23, 2014

\section{서 론}

파상풍은 Gram 양성 세균인 Clostridium tetani에서 분비하는 외독소에 의하여 신경계통에 급성중독 현상을 일으켜 국소적인 경 련에서 호흡마비까지 초래하는 치사율이 높고 심각한 합병증을 유 발할 수 있는 질환이다(Yoon 등, 2004).

세계보건기구의 통계에 따르면 파상풍의 전 세계적인 발병률은 1 년에 1 백만 명 정도로 추산되며, 사망률이 $20 \sim 30 \%$ 에 이르며 미 국에서는 1940년대 후반부터 파상풍에 대한 정규 예방접종이 시 작되면서, 파상풍 발병률이 지속적으로 감소하여 현재는 1 년에 50 례 이하로 보고되고 있다(CDC, 2006).
우리나라의 경우 1955 년에 파상풍 예방접종이 시작되었으며, 1958년부터 국립보건원에서 DPT 백신을 생산하여 본격적인 예방 접종이 실시되었다(Lee, 1995). 1980년대 DPT의 예방접종률이 $90 \%$ 를 상회하면서 신생아 파상풍은 거의 발생하고 있지 않지만 최 근 우리나라 질병관리본부의 통계에 따르면, 2000년도 20례, 2001년도 15례, 2002년도 17례, 2003년도 13례, 2004년도 16례, 2005년도 23례, 2006년도 18례, 2007년도 21례, 2008년도 16례, 2009년도 24례, 2010년도 14례로 최근까지도 꾸준히 파상풍 환 자가 보고되고 있다(질병관리본부, 2011).

그러나 유병률이 낮은 질환이기 때문에 응급실에서 자주 접할 수가 없으며, 미비한 응급검사 시스템과 비 특이적인 증상을 호소 
하는 환자가 많아 발병 초기에 정확한 진단이 어려운 것이 사실이 며, 예후에 관하여 외국에서 드물게 보고한 경우가 있지만 최근 연 구동향에 대한 자료가 부족하며, 국내에서도 파상풍 환자의 증상이 나 예후에 관한 연구가 적으며 관심의 대상에서 점점 제외되고 있 다.

미국 질병관리본부의 권고사항에 따르면 창상 발생 시 파상풍 백신 및 면역글로블린 투여 권고안을 제시하였지만, 여러 연구에 서 이에 대한 순응도가 낮다고 보고하고 있다(Ozturk 등, 2003; Abbate 등, 2008).

최근 응급실에서 파상풍 항체 신속 정성검사 키트의 유용성이 보 고가 되었으며, 이는 불필요한 파상풍 면역글로블린의 투여를 줄일 수 있는 수단으로 받아들여지고 있다(Samuel 등, 2001; Geraldine 등, 2002).

따라서 본 연구에서는 2005년 3월에서 2010년 12월 사이에 대 구지역의 응급의료센터를 내원한 파상풍 환자들을 대상으로 임상 적 특성과 유형을 조사하고 파상풍 항체 역가의 정성적인 검사를 위해 개발된 Tetanos Quick Stick (TQS) 현장검사 키트의 결과를 ELISA (enzyme-linked immunosorbent assay)로 측정한 결과와 비교하여 Tetanos Quick Stick 검사가 파상풍 예방 처치를 위한 선 별적인 검사로서의 가능성을 알아보고 파상풍 환자들을 신속하게 진단하며 빠른 응급검사와 처치 그리고 적절한 치료를 제공함으로 써 환자의 조기진단과 치료에 도움을 주고자 본 연구를 실시하였 다.

\section{재료 및 방법}

\section{1. 연구 대상}

2005년 3월부터 2010년 12월 사이에 대구광역시 소재 A병원 응급의료센터를 내원하여 입원 치료를 받은 20세 이상 파상풍환자 42례를 대상으로 하였다. 환자들의 의무기록과 임상기록을 토대로 임상병리학적 특성과 변화를 후향적, 전향적인 방법으로 조사하여 비교 분석하고, Tetanos Quick Stick의 유용성 평가연구를 위해 응 급센터를 내원한 환자 중 520명에게 TQS검사를 실시하여 ELISA 로 측정한 결과를 비교 분석 하였다. 연구를 진행하기 전 개인정보 수집과 이용에 관한 제공 동의서에 자필 서명한 환자에 대해서 연 구를 실시하였고, 연구과정 전반에 걸쳐 연구대상자에 대한 윤리적 측면을 고려하고, 개인 식별 자료는 직접 명시하지 않았으며, 유추 하여 신상을 파악할 수 있는 어떠한 자료도 제시하지 않았다.

\section{2. 검사방법}

연구에 사용된 TQS 키트(Biosite, CA, USA)는 면역크로마토그
래피(Immunochromatographic assay)을 이용한 정성 분석법으 로 파상풍 항체 유무를 판독 가능한 장비이며, 환자들로부터 전혈 $3 \mathrm{~mL}$ 를 채취하여 TQS에 한 방울 $30 \mathrm{uL}$ ) 떨어뜨리고 15 분 후 양성과 음성 여부를 확인하여 기록하고, $3,000 \mathrm{rpm}$ 으로 10 분간 원심분리 하여 얻은 혈청으로 ELISA 검사를 시행하였다. 검사 과정은 wash buffer를 증류수로 1:10 희석하여 working buffer를 만들고 검체 를 60분 동안 상온에서 방치한 후 working buffer로 희석하고 enzyme conjugate를 첨가하여 검체를 30분 동안 상온에서 방치한 후 다시 working buffer로 희석하고 TMB (tetramethylbenzidine) substrate를 첨가하여 working substrate solution을 만들고, 20분 동안 방치한 후 정지액(stop solution)을 넣어 반응을 정지시킨 다음 $450 \mathrm{~nm}$ 에서 흡광도를 측정하였다. TQS 검사 결과와 ELISA 검사 결과를 비교하여 정확도, 민감도, 특이도, 양성예측도, 음성예측도 를 구하였다.

\section{3. 통계분석}

자료의 분석은 윈도우용 SPSS version 18.0 (SPSS Institute, Chicago, IL, USA)를 이용하여 분석하였다. 변수는 t-test를 시행 하였고 결과 값은 평균과 표준편차로 표시하였다. 범주형 자료의 비교에는 $\mathrm{x}^{2}$ 을 사용하였고 기대 값이 작은 경우에는 Fisher의 직접 확률계산법을 이용하였다. 모든 통계 분석을 위한 유의수준 $(p)$ 은 $p$ $<0.05$ 로 설정하였다.

\section{결 과}

\section{1. 파상풍 환자의 임상적 특징}

전체 환자 42명 중에서 생존군은 33명(78.6\%), 사망군은 9명 (21.4\%)이었고, 연령은 생존군이 $52.3 \pm 14.5$ 세, 사망군은 $54.5 \pm 16.1$ 세이었으며 전체 평균연령은 $53.4 \pm 15.3$ 세 이었다. 남 녀 성별 발생 분포는 남자 31 례(73.8\%), 여자 11례(26.2\%)로 남자 에게서 호발하였다. 계절별로는 여름(6월 8월)이 19례(45.3\%)로 가장 많이 발생하였으며, 봄(3월 5월) 11례(26.2\%), 가을(9월 11월) 9례(21.4\%), 겨울철(12월 2월) 3례(7.1\%) 순이었고, 응급 의료센터 내원당시 진단명은 전해질 불균형 14 례(33.3\%), 말초신 경병증 11례(26.2\%), 뇌수막염 8례(19.0\%), 약물중독 7례(16.7\%) 순이었으며 파상풍으로 진단된 환자는 2례(4.8\%)였다(Table 1).

\section{2. 임상적 증상에 따른 비교}

대부분의 환자들은 경련과 경부 강직으로 내원하였으며 시간이 경과할수록 호흡곤란을 호소하였다. 전체 42 명의 환자에서 나타난 모든 임상적 증상을 조사하였을 때 호흡곤란 38 례(90.5\%), 경련 32 
Table 1. Patient general characteristics

\begin{tabular}{|c|c|c|c|c|}
\hline & Survival & Death & Total (\%) & $p$-value \\
\hline Total (\%) & $33(78.6 \%)$ & $9(21.4 \%)$ & $42(100 \%)$ & \\
\hline Mean age (year) & $52.3 \pm 14.5$ & $54.5 \pm 16.1$ & $53.4 \pm 15.3$ & 0.041 \\
\hline Male & 24 & 7 & $31(73.8 \%)$ & 0.318 \\
\hline Female & 9 & 2 & $11(26.2 \%)$ & \\
\hline \multicolumn{5}{|l|}{ Seasonal frequency } \\
\hline Spring & 9 & 2 & $11(26.2 \%)$ & 0.146 \\
\hline Summer & 14 & 5 & $19(45.3 \%)$ & \\
\hline Autumn & 7 & 2 & $9(21.4 \%)$ & \\
\hline Winter & 3 & 0 & $3(7.1 \%)$ & \\
\hline \multicolumn{5}{|l|}{ Tentative diagnosis } \\
\hline Eletrolyte imbalance & 10 & 4 & $14(33.3 \%)$ & 0.287 \\
\hline Peripheral neuropathy & 8 & 3 & $11(26.2 \%)$ & \\
\hline Encephalomeningitis & 7 & 1 & $8(19.0 \%)$ & \\
\hline Drug intoxication & 7 & 0 & $7(16.7 \%)$ & \\
\hline Tetanus & 1 & 1 & $2(4.8 \%)$ & \\
\hline
\end{tabular}

Table 2. Signs and symptoms of the patients. $\mathrm{N}=(\%)$

\begin{tabular}{lcccc}
\hline & Survival & Death & Total $(\mathrm{N}=42)$ & $p$-value \\
\hline Dyspnea & 30 & 8 & $38(90.5 \%)$ & 0.142 \\
Spasm & 26 & 6 & $32(76.2 \%)$ & \\
Nuchal rigidity & 18 & 6 & $24(57.1 \%)$ & \\
Dysarticulation & 12 & 4 & $16(38.1 \%)$ & \\
Chest pain & 10 & 3 & $13(31.0 \%)$ & \\
\hline
\end{tabular}

례(76.2\%), 경부강직 24례(57.1\%), 구음장애 16례(38.1\%), 흥통 13례(31.0\%) 순으로 증상을 호소하였다(Table 2).

\section{3. 파상풍 항체 양성율과 TQS kit의 유용성}

응급의료센터를 내원한 환자 520명에서 TQS는 42명(8.07\%)에 서 양성이었고, 음성은 478명이었다. ELISA 검사결과는 0.1 $\mathrm{IU} / \mathrm{mL}$ 이상을 양성으로 했을 때 ELISA 양성은 48명(9.23\%) 이었 고, 음성은 472명이었다. 이에 따른 TQS 검사의 정확도(98.0\%), 민 감도(83.3\%), 특이도(99.5\%), 양성예측도( $95.2 \%)$, 음성예측도 (98.3\%) 였다(Table 3).

\section{고 찰}

파상풍은 골격근의 강직과 경련성 수축을 특징으로 하는 질환으 로 원인균인 Clostridium tetani는 혐기성 그람 양성의 포자를 형 성하는 간균으로 혐기성 상황이 만들어지면 괴사된 조직내에서 쉽 게 발아된다. 이는 대부분 급성 손상 후에 발생하나 피부 궤양, 농 양, 또는 비경구적인 약물남용과 같은 만성적인 상처에서도 발생된 다(Geraldine 등, 2002).

C. tetani에 의한 감염은 국소적이며 신경독소인 tetanoplasmin
Table 3. Results of ELISA and tetanos quick stick

\begin{tabular}{|c|c|c|c|c|}
\hline & & \multicolumn{2}{|c|}{ ELISA } & \multirow{2}{*}{ Total } \\
\hline & & + & - & \\
\hline TQS & + & 40 & 2 & $\begin{array}{c}42 \\
8.07 \%\end{array}$ \\
\hline & - & 8 & 470 & 478 \\
\hline Total & & $\begin{array}{c}48 \\
9.23 \%\end{array}$ & 472 & 520 \\
\hline
\end{tabular}

Accuracy $=(40+470) / 520=0.980$, Sensitivity $=40 / 48=0.833$, Specificity $=470 / 472=0.995$, Positive predictive value $=40 / 42=0.952$, Negative predictive $=470 / 478=0.983$.

이 세균의 융해에 의해 분비되고 이는 축삭을 타고 전달되어 전각 억제 신경에 높은 친화력과 특이도를 보이며 신경전달물질의 분비 를 차단시켜 결과적으로 근육의 수축, 강직, 반사성 경련을 일으키 며, 주로 5월 10월 사이에 개발도상국가를 비롯한 남부지방에서 발병하며 지역분포가 치중된 이유는 무더운 기후와 C. tetani가 유 기물이 풍부한 토양 속에 존재한다는 점과 경제빈곤으로 인한 면역 률저하와 비위생적인 출산기술에 기인한다(Aydin 등, 2006).

이에 상처가 발생했을 때 파상풍 감염 위험이 항상 존재하지만, 예방접종의 보급에 따른 항체 역가의 상승으로 발병률이 현저하게 감소하였으며 실제로 파상풍에 걸린 환자들의 파상풍 항체를 분석 한 연구에 따르면, 대부분의 환자들이 충분한 항체를 가지고 있지 못하였다(Pascual 등, 2003).

1927년 백신 개발 이후 1940년대부터 체계화된 예방접종의 실 시 결과 파상풍의 발생빈도는 현저히 줄어들어 1947년 10만 명 당 0.39 의 유병률이 1990 년에는 10 만 명 당 0.02 로 감소하였고, 이는 응급의료센터에서의 적절한 상처 처치와 예방이 감소 추세에 기여 하는 바가 크다고 할 수 있다(CDC, 1991). 
우리나라에서는 파상풍예방을 위하여 디프테리아, 파상풍, 톡 소이드에 백일해 사균을 첨가한 DPT를 생후 $2,4,6$ 개월에 기본 접 종을 하고 있으며 18개월과 4 6세에 추가 접종 후 10년마다 예방 백신을 추가 접종할 것을 권장하고 있으나, 실제로는 유소아기 이 후에는 추가 접종이 시행되지 않기에 소아 및 성인층의 파상풍 항 체 역가는 나이가 들수록 급격히 감소하고 특히 60세 이상에서는 대다수가 파상풍 예방 가능한 항체 역가가 낮게 나타난다(홍, 2001).

20세 이상의 젊은 연령층에서 35 40\%도 파상풍 예방 항체역 가에 못 미치어 모든 성인과 60 세 이상의 노년층에서는 적극적인 예방을 권고하고 있으며(Gergen 등, 1995), 항체역가에 관한 자료 에 따르면 과거 파상풍 최소 방어 항체의 역가는 동물 실험을 통해 $0.01 \mathrm{IU} / \mathrm{mL}$ 로 알려져 있으나 최근에는 ELISA 검사에 의해 0.1 $\mathrm{IU} / \mathrm{mL}$ 또는 그 이상으로 해야 한다고 보고하고 있으며(Shohat 등, 2000), 우리나라의 경우 DPT 접종률은 1차 98.7\%, 2차 98.0\%, 3 차 $95.3 \%$ 이며, 추가 접종률은 $75.8 \%$ 로 보고하고 있으나 성인의 $11.6 \%$ 만이 파상풍 최소방어 항체역가를 보유하고 있는 것으로 나 타났다(손 등, 2004).

본 연구에서는 응급의료센터에 내원한 파상풍 환자들의 임상적 인 특징을 조사하고, 파상풍 항체 역가검사를 위해 개발된 TQS 현 장검사 키트결과를 ELISA로 측정한 결과와 비교하여 TQS검사가 파상풍 예방 처치를 위한 신속 정확한 응급검사로서의 유용성을 알 아보았다.

전체 환자 42명 중에서 생존군은 33명(78.6\%), 사망군은 9명 (21.4\%)이었고, 연령은 생존군이 $52.3 \pm 14.5$ 세, 사망군은 $54.5 \pm 16.1$ 세이었으며 전체 평균연령은 $53.4 \pm 15.3$ 세 이었다. 남 녀 성별 발생 분포는 남자 31 례(73.8\%), 여자 11례(26.2\%)로 여성 보다는 남성에게서 더욱 호발하는 것을 알 수 있었고, 계절별로는 다른 연구에서와 마찬가지로 여름(6월 8월)이 19례(45.2\%)로 가 장 많이 발생하였으며, 응급의료센터 내원당시 진단명은 전해질 불 균형 14례(33.3\%), 말초신경병증 11례(26.2\%), 뇌수막염 8례 (19.0\%), 약물중독 7례(16.7\%) 순이었으며 내원 초기에 파상풍으 로 진단된 환자는 2례(4.8\%)였다. 대부분의 환자들은 호흡곤란 38 례(90.5\%), 경련 32례(76.2\%), 경부강직 24례(57.1\%), 구음장애 16례(38.1\%), 훙통 13례(31.0\%) 순으로 증상을 호소하였다.

$\mathrm{TQS}$ 의 유용성을 ELISA와 비교 평가한 결과 정확도(98.0\%), 민 감도(83.3\%), 특이도(99.5\%), 양성예측도(95.2\%), 음성예측도 (98.3\%)의 결과를 보여 응급의료센터에서 선별적인 파상풍 예방 처치의 결정에 유용하게 이용 될 수 있을 것으로 사료되고, TQS 검 사는 파상풍에 대한 환자의 현재 면역상태에 대한 평가가 가능하 고, 결과적으로 불필요한 백신, 면역글로불린 투여로 인한 부작용
예방의 장점이 있으며, 체계적으로 추가접종이 실시되지 못하는 우 리나라의 현실에서 50세 이전에는 비교적 저렴한 TQS kit 검사를 이용하여 불필요한 면역글로불린의 투여를 줄임으로써 의료비용 절감 효과를 기대할 수 있을 것이다. 하지만 정확히 어느 연령을 기 준으로 TQS 검사를 시행하는 것이 바람직한지는 향후 대 규모의 연 구가 필요할 것으로 사료되며, 본 연구에서는 파상풍 항체 양성율 이 $9.23 \%$ 로 손 등의 연구결과 $11.6 \%$ 보다 낮게 측정되었다. 이러한 결과는 추가접종이 필요함을 제시하는 결과라고 생각된다.

본 연구의 제한점으로는 피험자의 교육수준, 경제적 능력 등의 추가적인 요인을 연구 분석에 포함하지 못한 점과 조사 지역이 단 일지역이라는 점이다. 따라서 통계학적으로 의미 있는 피험자의 수 와 추가적인 요인을 포함한 전 지역을 대상으로 하는 연구가 반드 시 필요할 것으로 생각된다.

마지막으로 현재 우리나라 응급의료센터에서 성인용 파상풍 백 신을 얼마나 접종하고 있는지에 대한 조사가 필요하며, 성인용 파 상풍 백신 접종이 활성화 된 후에 이전 파상풍 예방접종력이 파상 풍 항체 역가에 어떠한 영향을 미치는지에 대한 연구가 필요할 것 으로 보이며, 이러한 연구가 국가적인 파상풍 예방접종 사업에 도 움이 될 것으로 생각되고, 결론적으로 TQS 검사키트의 사용은 파 상풍 환자를 1 차적으로 접하고 응급처치를 하는 응급의료진에게 객관적인 진단적 자료를 제공함으로써 파상풍환자의 예방처치 및 응급검사에 많은 도움을 줄 수 있을 것으로 사료된다.

\section{참고문헌}

Abbate R, Di Giuseppe G, Marinelli P, Angelillo IF. Collaborative Working Group. Appropriate tetanus prophylaxis practices in patients attending emergency departments in Italy. Vaccine. 2008, 26:3634-3639.

Aydin K, Yilmaz G, Aksoy F, Koksal I. An analysis of the factors effecting the prognosis of tetanus in a university hospital between 1991 and 2005. Clinical Microbiology \& Infection. 2006, 12:1094-1097.

Center for Disease Control. Diphtheria, tetanus, and pertussis: Recommendations for vaccine use and other preventive measures recommendations of the immunization practices advisory committee (ACIP). MMWR. 1991, 40:1-28.

Centers for Disease Control. Tetanus Surveillance-United States 2003-2005 MMWR. 2006, 47:1-11.

Geraldine M, Mcquillan GM, Deanna KM. Serologic immunity to diphtheria and tetanus in the United States, Ann intern Med. 2002, 136:660-666.

Gergen PJ, Mcquillan GM, Kiely M. A population-based serologic survey of immunity to tetanus in the United States. $N$ Engl J Med. 1995, 332:761-766.

Ozturk A, Goahmetoglu S, Erdem F. Tetanus antitoxin levels among adults over 40 years of age in Central Anatolia, Turkey. Clin Microbiol Infect. 2003, 9:33-38. 
16 Seung Jin Lee, et al. Clinical Characteristics and Tetanus Quick Stick Evaluation for Tetanus Patients

Pascual FB, Mcginley EL, Zanardi LR, Cortese MM, Murphy TV. Tetanus Surveillance-United States, 1998-2000. MMWR Surveill Sum. 2003, 52:1-8.

Samuel SH, Georgina G. Tetanus in the emergency department; a current review. J Emerg Med. 2001, 20:357-365.

Shohat T, Marva E, Sivan Y, Leman J, Mates A, Chen A. Immunologic response to a single dose of tetanus toxoid in older people. J Am Geriatr Soc. 2000, 48:949-951.
Yoon YS, Kim EC, Lee WH, Chung SW, Yi JH, Park IC. Utility of tetanus quick stick test for selective tetanus prophylaxis. J Korean SOC Emerg Med. 2004, 15:95-101.

손유동, 임경수, 최욱진, 안지윤, 김원, 최윤백 등. 한국인의 항 파상풍 항체의 정성적 조사. 대한외상학회지. 2004, 17:27-36.

질병관리본부(2011). 손상감시정보. http://www.cdc.go.kr/, 2013-09-30 에 최종방문.

홍창의. 소아과학. 7판, 대한교과서, 2001, p386-389. 